Volume: 8

Issue: 2

Month: October

Year: 2020

P-ISSN: 2321-4643

E-ISSN: 2581-9402

Received: 10.08 .2020

Accepted: 29.09.2020

Published: 01.10.2020

Citation:

Margaret Divya, A., and Nandhinidevi. "A Study on Passengers Satisfaction towards Indian Railway Services (With Special Reference to Madurai City)." Shanlax International Journal of Management, vol. 8, no. 2, 2020, pp. 79-84.

DOI:

https://doi.org/10.34293/ management.v8i2.3336

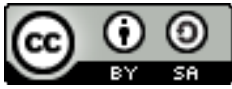

This work is licensed under a Creative Commons AttributionShareAlike 4.0 International License.

\author{
A. Margaret Divya
}

Assistant Professor, Department of Commerce

Lady Doak College, Madurai, Tamil Nadu, India

https://orcid.org/0000-0001-9675-9238

Nandhinidevi

Department of Commerce, Lady Doak College, Madurai, Tamil Nadu, India

Abstract

India is one of the largest countries in terms of geographical size, which requires efficient means for long-distance transportation. Public transport, being the primary mode of transport, remains a powerful yardstick to measure the overall development of a nation. Among the various modes of transport, Railways are one of the biggest modes of passenger transport in the world. The Railway passenger services face long term competitive threats from airlines, luxury buses, personalized transport, and improved public transport. To compete with other modes of transport, it is inevitable for railways to accelerate the growth of passenger's origination. It is essential for the railway authorities to know the opinion of the passengers regarding the services offered to them to make future policies and provisions. Having this drive in mind, the researchers have undertaken a study about the services provided by the Indian Railways along with its objectives to analyze the passengers' preferences, satisfaction, limitations, and perceptions towards the same. Every aspect related to railway services like ticket availability, quality of travel, employee behavior, safety, timing, and other relevant aspects is analyzed at different levels of the research. As passenger satisfaction is chosen to be the concept for this research, elements that allow passengers to feel satisfied with offered services are also mentioned in the theoretical part. The scope of this project is limited to passengers of Madurai city.

Keywords: Earmarking, Reservation, Amenities, Obviating, Pantry Car and Luggage Rack

\section{Introduction}

The Indian Railway is one of the largest railway networks in the world. Indian Railways is India's national railway system operated by the Ministry of Railways. Indian Railway runs more than 20,000 passenger trains daily, on both long-distance and suburban routes, from 7,349 stations across India. Most premium passenger trains like Rajdhani, Shatabdi Exp run at a peak speed of $145 \mathrm{~km} / \mathrm{h}$ (90 mph), with Gatiman Express between New Delhi and Jhansi touching peak speed of $160 \mathrm{~km} / \mathrm{h}(99 \mathrm{mph})$. A suburban railway provides various facilities to the people, such as low fare, comfortable journey, speed, the security of the passengers, ticket availability, and coaches to the passengers.

\section{Statement of the Problem}

As the population of the country increases day by day, and the majority of the people opt for railway services based on their affordability. Still, railways are far more important in most the human lives.

\title{
OPEN ACCESS \\ Manuscript ID: \\ MGT-2020-08023336 \\ A Study on Passengers Satisfaction towards Indian Railway Services (With Special Reference to Madurai City)
}


The researchers, by giving due consideration to this fact, want to analyze on the provision of Railway services and the perception about such services from the passengers and this being the concept underlying the study, the main focal point is that to know the role played by the Indian Railway services in the lives of its passengers.

\section{Scope of the Study}

The study deals with the provision and evaluation of passenger amenities and the services rendered to the passengers by Indian railways. The study mainly focuses on the satisfaction level of the passengers from the services offered by Indian railways. The scope of this project is limited to passengers of Madurai city.

\section{Objectives of the Study}

1. To know the services provided to the passengers by the Indian railways.

2. To know a perception of respondents about various services provided by the Indian Railways.

3. To identify the most preferred services so that these can be strengthened to optimize passenger satisfaction.

4. To estimate the overall satisfaction level of passengers in the Indian railways.

\section{Methodology of the Study}

This study is descriptive and analytical and adopts a survey method for its study. This study depends mainly on the primary data collected though the wellstructured questionnaire among the respondents. During the period of study, all relevant published information is collected; formal and informal discussions are conducted with the passengers.

Primary Data: Primary data is the information collected directly from the respondents. It is firsthand information. Primary data is collected from passengers who use railway services.

Secondary Data: Secondary data are data that has already been collected by someone. Secondary data is collected from books, journals, websites, and newspapers.

Period of the Study: The period of the study is 2019-2020.
Sample Design: The sampling technique adopted is the Simple Random Sampling technique.

Statistical Analysis: Simple techniques such as Percentage, Bar diagrams, Mean, Garret Ranking, and Likert Scaling were applied using SPSS 11.0 software package in various factors of Indian Railways services for the determination of associations between the groups and other components.

\section{Limitations of the Study}

The study is mainly based on the information collected from the respondents, and the factors given by them are subjective.

The study mainly covers Madurai city, so it may vary in other cities and after some time.

\section{Analysis and Interpretation \\ Demographic Features}

The respondents comprise $36 \%$ of the respondents who belong to the age group 20-40 years avail more services offered by the Indian railway when compared to the other age group of people. It is found that 53\% of the respondents are female respondents and $43 \%$ of the respondents are male respondents. $25 \%$ of the respondents are unmarried. It was identified that $20 \%$ of the respondents are under graduates and Diploma Holders. $20 \%$ of the respondents are students, and $5 \%$ of the respondents are other categories. It was observed that $33 \%$ of the respondents have an annual income of above Rs.15001-25,000 had highly availing railway services.

Table 1: Availance of Indian Railway Services

\begin{tabular}{|c|c|c|c|}
\hline Title & Category & Frequency & $\%$ \\
\hline \multirow{6}{*}{$\begin{array}{c}\text { Availance } \\
\text { of Indian } \\
\text { railway } \\
\text { services }\end{array}$} & Daily & 40 & $40 \%$ \\
\hline & Weekly & 13 & $13 \%$ \\
\hline & Occasionally & 12 & $12 \%$ \\
\hline & Once in a year & 16 & $16 \%$ \\
\hline & Twice in a year & 19 & $19 \%$ \\
\hline & Total & 100 & $100 \%$ \\
\hline
\end{tabular}

Source: Primary Data

From Table 1, it is observed that $40 \%$ of the respondents utilize the Indian railway services daily, and $12 \%$ of the respondents utilize occasionally. 


\begin{tabular}{|c|l|c|c|}
\hline \multicolumn{4}{|c}{ Table 2: Purpose of Travel } \\
\hline \multirow{4}{*}{ Title } & \multicolumn{1}{|c|}{ Category } & Frequency & $\%$ \\
\hline \multirow{4}{*}{$\begin{array}{c}\text { Purpose } \\
\text { of } \\
\text { Travel }\end{array}$} & Education & 12 & $12 \%$ \\
\cline { 2 - 4 } & Employment & 20 & $20 \%$ \\
\cline { 2 - 4 } & Personal & 16 & $16 \%$ \\
\cline { 2 - 4 } & Emergency Situation & 14 & $14 \%$ \\
\cline { 2 - 4 } & Tourism & 12 & $12 \%$ \\
\cline { 2 - 4 } & Others & 18 & $18 \%$ \\
\cline { 2 - 4 } & Total & $\mathbf{1 0 0}$ & $\mathbf{1 0 0} \%$ \\
\hline
\end{tabular}

Source: Primary Data

From Table 2, it was found that $20 \%$ of respondents travel for employment purposes and $8 \%$ of the respondents for other purposes.

Table 3: Types of Passenger Train

\begin{tabular}{|c|l|c|c|}
\hline Title & Category & Frequency & $\mathbf{\%}$ \\
\hline \multirow{4}{*}{$\begin{array}{c}\text { Types of } \\
\text { Passenger } \\
\text { Trains }\end{array}$} & Passenger & 17 & $17 \%$ \\
\cline { 2 - 4 } & Express & 30 & $30 \%$ \\
\cline { 2 - 4 } & Superfast & 36 & $36 \%$ \\
\cline { 2 - 4 } & Others & 17 & $17 \%$ \\
\cline { 2 - 4 } & Total & $\mathbf{1 0 0}$ & $\mathbf{1 0 0 \%}$ \\
\hline
\end{tabular}

Source: Primary Data

From Table 3, it was concluded that $36 \%$ of the respondents frequently use a superfast train and 17\% of the respondents use passenger trains and other types of trains.

Table 4: Class of Travel

\begin{tabular}{|c|l|c|c|}
\hline Title & Category & Frequency & $\mathbf{\%}$ \\
\hline \multirow{5}{*}{$\begin{array}{c}\text { Class of } \\
\text { Travel }\end{array}$} & Second class & 8 & $8 \%$ \\
\cline { 2 - 4 } & Sleeper & 21 & $21 \%$ \\
\cline { 2 - 4 } & AC Chair car & 11 & $11 \%$ \\
\cline { 2 - 4 } & First class & 15 & $15 \%$ \\
\cline { 2 - 4 } & AC 3-Tier & 13 & $13 \%$ \\
\cline { 2 - 4 } & AC 2-Tier & 15 & $15 \%$ \\
\cline { 2 - 4 } & AC First class & 17 & $17 \%$ \\
\cline { 2 - 4 } & Total & $\mathbf{1 0 0}$ & $\mathbf{1 0 0} \%$ \\
\hline
\end{tabular}

Source: Primary Data

From Table 4, it is found that $21 \%$ of the respondents travel in the sleeper class, and $8 \%$ of the respondents travel in second class.
Table 5: Mode of Ticket Booking

\begin{tabular}{|c|l|c|c|}
\hline Title & Category & Frequency & $\mathbf{\%}$ \\
\hline \multirow{4}{*}{$\begin{array}{c}\text { Mode of } \\
\text { Tickets } \\
\text { booking }\end{array}$} & At Booking counter & 26 & $26 \%$ \\
\cline { 2 - 4 } & Through agents & 32 & $32 \%$ \\
\cline { 2 - 4 } & IRCTC website & 32 & $32 \%$ \\
\cline { 2 - 4 } & Any others & 10 & $10 \%$ \\
\cline { 2 - 4 } & Total & $\mathbf{1 0 0}$ & $\mathbf{1 0 0 \%}$ \\
\hline
\end{tabular}

Source: Primary Data

From Table 5, it was found that $32 \%$ of the respondents book tickets through agents and the IRCTC Website and $10 \%$ of the respondents use other ways of booking tickets.

Table 6: Concession in Ticket Booking

\begin{tabular}{|c|c|c|c|}
\hline Title & Category & Frequency & $\%$ \\
\hline \multirow{3}{*}{$\begin{array}{l}\text { Concession } \\
\text { in ticket } \\
\text { booking }\end{array}$} & Yes & 48 & $48 \%$ \\
\hline & No & 52 & $52 \%$ \\
\hline & Total & 100 & $100 \%$ \\
\hline \multirow{11}{*}{$\begin{array}{l}\text { If Yes, tick } \\
\text { the type of } \\
\text { concession } \\
\text { you are } \\
\text { availing }\end{array}$} & No & 52 & $52 \%$ \\
\hline & Sportsman & 4 & $4 \%$ \\
\hline & Senior citizen & 10 & $10 \%$ \\
\hline & Diseased person & 2 & $2 \%$ \\
\hline & $\begin{array}{l}\text { Teacher / Students } \\
\text { of school / colleges }\end{array}$ & 2 & $2 \%$ \\
\hline & $\begin{array}{l}\text { Ex-Service men/ } \\
\text { army / navy / air } \\
\text { force }\end{array}$ & 9 & $9 \%$ \\
\hline & $\begin{array}{l}\text { Family members } \\
\text { of military / } \\
\text { air force / navy } \\
\text { personnel }\end{array}$ & 7 & $7 \%$ \\
\hline & $\begin{array}{l}\text { Government award } \\
\text { winners }\end{array}$ & 4 & $4 \%$ \\
\hline & $\begin{array}{l}\text { Physically } \\
\text { challenged }\end{array}$ & 5 & $5 \%$ \\
\hline & $\begin{array}{l}\text { Government } \\
\text { servants }\end{array}$ & 5 & $5 \%$ \\
\hline & Total & 100 & $100 \%$ \\
\hline
\end{tabular}

Source: Primary Data

From Table 6 , it was concluded that $52 \%$ of the respondents do not avail of any concession, and $48 \%$ of the respondents avail the concession in the process of ticket booking. 
International Journal of Management

Table 7: Passengers Preference Towards Indian Railways Services

\begin{tabular}{|l|c|c|c|}
\hline \multicolumn{1}{|c|}{ Particulars } & Total & $\begin{array}{c}\text { Mean } \\
\text { Score }\end{array}$ & $\begin{array}{c}\text { Garret } \\
\text { Rank }\end{array}$ \\
\hline Less cost and Affordable & 5859 & 58.59 & 1 \\
\hline On time arrival and Departure & 5461 & 54.61 & 2 \\
\hline Customer friendly services & 5185 & 51.85 & 3 \\
\hline Pantry Car & 4880 & 48.80 & 7 \\
\hline Safe and Secured & 5183 & 51.83 & 4 \\
\hline Convenient and Comfortable & 4907 & 49 & 6 \\
\hline $\begin{array}{l}\text { Proper maintenance of } \\
\text { sanitation }\end{array}$ & 5142 & 51.42 & 5 \\
\hline No traffic congestion & 4739 & 47.39 & 8 \\
\hline $\begin{array}{l}\text { Accessibility to various } \\
\text { venues from station }\end{array}$ & 4226 & 42.26 & 10 \\
\hline $\begin{array}{l}\text { No maximum limit for } \\
\text { luggage }\end{array}$ & 4359 & 43.59 & 9 \\
\hline
\end{tabular}

Source: Primary Data

From the Table 7, it can be explained that the item "Less cost and Affordable" ranks first in the opinion of the respondents, and "Accessibility to various venues from station "ranks tenth in the opinion of the respondents.

Table 8: Passenger's Satisfaction towards Indian Railway Services

\begin{tabular}{|l|c|}
\hline \multicolumn{1}{|c|}{ Particulars } & $\begin{array}{c}\text { Mean } \\
\text { Score }\end{array}$ \\
\hline Berths and toilet facilities & 3.26 \\
\hline Availability drinking water & 3.01 \\
\hline Proper working of electrical compliances & 2.83 \\
\hline Facilities for physically challenged person & 2.96 \\
\hline Inside ambience & 2.58 \\
\hline Parking space outside & 2.67 \\
\hline Mobile charging facilities & 2.62 \\
\hline E-booking facilities & 2.87 \\
\hline Festival offers & 2.69 \\
\hline Summer specials & 2.46 \\
\hline Tatkal services & 2.72 \\
\hline Trolley services & 2.87 \\
\hline Clock room/waiting room & 2.52 \\
\hline Working hours of reservation counter & 2.75 \\
\hline Information accessibility & 2.48 \\
\hline & $\mathbf{4 1 . 2 9}$ \\
\hline Clean toilets & 1.94 \\
\hline
\end{tabular}

\begin{tabular}{|l|c|}
\hline $\begin{array}{l}\text { Platform cleanliness/placement of dustbins } \\
\text { and its regular disposal }\end{array}$ & 2.49 \\
\hline Cleanliness on railway track & 2.59 \\
\hline Adequate water facilities & 2.68 \\
\hline Regular washing of bedsheet and towels & 2.57 \\
\hline & $\mathbf{1 2 . 2 7}$ \\
\hline General safety of passengers & 2.62 \\
\hline Safety of belonging & 2.64 \\
\hline Provision of CCTV camera & 2.69 \\
\hline Applicability of apps & 2.81 \\
\hline Foot over bridges (FOBS) & 2.38 \\
\hline & $\mathbf{1 3 . 1 4}$ \\
\hline Affordability of price & 2.67 \\
\hline Quality of the items & 2.74 \\
\hline Quantity of items & 2.62 \\
\hline Timely delivery & 2.78 \\
\hline Variety of items & 2.67 \\
\hline & $\mathbf{1 3 . 4 8}$ \\
\hline Behavior of railway employees & 2.77 \\
\hline Emergency helpline for passenger & 2.71 \\
\hline Response to phone enquiry & 2.57 \\
\hline Services by railway police department & 2.78 \\
\hline Services TTE coach attender & 2.73 \\
\hline & $\mathbf{1 3 . 5 6}$ \\
\hline & \\
\hline
\end{tabular}

Source: Primary Data

The above table 8 states that the passenger's level of satisfaction towards Indian railway services is the highest concerning the basic facilities, and it is less regarding the hygienic conditions.

The comfort of the Passengers: About the comfortability in Indian railways, the study says that special trains that were introduced to clear the extra rush during the festival days are higher with a mean score of 3.74, availability of separate coaches for disabled persons with easy entering is well displayed with a mean score of 3.64 and complaint books and suggestion box are always available at the station is lowest with a mean score of 3.19, Self-help Trolley is always available for use with a mean score of 3.16 .

\section{Suggestions}

1. More focus on quality food items, basic facilities, hygienic, and safe environment has to be improvised in the station. 
2. The numbers of general compartments have to be increased to reduce the overcrowding in the trains.

3. The authority has to take the necessary step to cut down ticket prices because most of the rail passengers are middle-income group people.

4. The availability of sufficient and clean water should be ensured.

5. The sophisticated waiting room services need to be maintained, and the charge can be considerably reduced for the sake of all the passengers.

6. Installation of CCTV cameras in every compartment, touch screen system for inquiries (working condition), ticket checking at the train doorstep, and provision of television and audio systems at an increased rate would facilitate the management in a more systematic way to run the trains in a cost-effective way and to reduce the crimes both at state and national level.

7. Regular cleaning of the toilets is a great need of the hour expected by almost all the passengers.

\section{Conclusion}

The empirical study is a contribution to identify the factors that determine passenger satisfaction in railway services and the quality of services provided by the Central Government in the city of Madurai. Accordingly, this research gives some insights to develop and improve the quality of services to satisfy the passengers in a better way concerning rail transport.

\section{References}

Agarwal, Reeti. "Public Transportation and Customer Satisfaction: The Case of Indian Railways." Global Business Review, vol. 9, no. 2, 2008, pp. 257-272.

Amudha, R., et al. "Upshot of ICT in Indian Railways on Passenger Satisfaction- Using Railqual." International Conference on Computation of Power, Energy, Information and Communication, 2018, pp. 98-102.

Bhandari, Laveesh. Rail Pricing \& Efficiency, 2000. Bharathi, N. "Customers Perception of Indian Railways (Special Reference To Coimbatore Region)." Tecnia Journal of Management Studies, vol. 5, no. 1, 2010, pp. 6-14.
Chandran. "Services Marketing - A Case Study of South Central Railway (SCR)." Finance Indian, vol. 18, no.3, 2003.

Devi Prasad, M., and B.Raja Shekhar. "Development of Railqual: A Service Quality Scale for Measuring Indian Railway Passenger Services." Management Science and Engineering, vol. 4, no. 3, 2010, pp. 87-94.

Goto, Koichi. "Passenger Services Technologies." Japan Railway and Transport Review, 2001.

"Indian Railway Service of Engineers." Wikipedia, https://en.wikipedia.org/wiki/Indian Railway_Service_of_Engineers

"Indian Railways Services: Top 5 Amenities Offered for Comfort of Passengers." NDTV, 2018

Jeganathan, G. Commuters of Railways - An Attitude Study with Special Reference to Thirunelveli Nagarcoil Section, Manonmaniam Sundaranar University, 2002.

Joshep, M. Customer Satisfaction in Southern Railway, Madurai Division, Thigarajar School of Management, 2000.

Pollitt, Michael G., and Andrew S.J. Smith. "The Restructuring and Privatization of British Rail: was it Really that Bad?" Fiscal Studies, vol. 23, no. 4, 2002, pp. 463-502.

Praveena, et al. "Smart Railway Gate Obstacle Detection and Warning System." International Journal of Computer Science and Mobile Computing, vol. 9, no. 3, 2020, pp.199-205.

Rama Prasad, M.V. "A Study on Passenger Amenities in Railways." Indian Journal of Marketing, 2002.

Rao, D. Panduranga, and B. Rama Rao. "Factors Influencing the Transport Behavior of Man." Journal of Transport Management, 1984.

Sehgal, Parmod Chand. A Comparative Analysis of Motivation and Job Satisfaction Level of Employees of Different Departments in Indian Railways, Saurashtra University, 2011.

Shanmugam, T.R. Marketing of Railways Services - A Study of Passenger and Goods Traffic in Madurai Junction, Madurai Kamaraj University, 1987.

Sheeba, A.A., and K.Kumuthadevi. "Service Quality of South Indian Railway-Determinants of Passenger Satisfaction in Trains." 
International Journal of Management

International Journal of Business and

Management Invention, vol. 2, no. 2, 2013, pp. 49-54.

Shrivastva, Chitresh, and Mahmoud Ali. "HighSpeed Rail Corridor: The Indian Assessment." Journal of Management \& Public Policy, vol. 10, no. 2, 2019, pp. 21-32.

Srivastava, Anoop, et al. "Analysis of Interpretive Structural Model of Indian Railway Security

System by Analytic Hierarchy Process

(AHP)." Journal of Advances in Management Research, vol. 16, no. 3, 2019, pp. 378-397. Thirumoorty, R. Consumer Images of Indian Railways - A Study in Madurai Railways Station, Madurai Kamaraj University, 2001. http://www.indianrail.gov.in/enquiry/StaticPages/ StaticEnquiry.jsp?StaticPage $=$ index.html http://www.indianrailways.gov.in/railwayboard/

\section{Author Details}

Dr. Margaret Divya, Assistant Professor, Department of Commerce, Lady Doak College, Madurai, Tamil Nadu, India,Email ID: mdmdivya982@gmail.com.

Ms. Nandhinidevi, Department of Commerce, Lady Doak College, Madurai, Tamil Nadu, India,

Email ID: 18pgce16@ldc.edu.in. 